\title{
The Economic Causes of War and Changes in Post-War Economic Thought: From Keynes to Beneš
}

\section{Tomáš NIKODYM}

Katedra hospodářských dějin, Národohospodářská fakulta, Vysoká škola ekonomická v Praze Department of Economic History, Faculty of Economics, University of Economics in Prague nám. Winstona Churchilla 4, 13067 Praha, Czech Republic nikodym.tomas@gmail.com

"Peace is the natural effect of trade." Charles Louis Montesquieu

"Commerce, which ought naturally to be among nations as among individuals, a bond of union and friendship, has become the most fertile source of discord and animosity."

Adam Smith

When people endeavor to find the cause of war, this is, of course, only the half of their goal. The second half is the proposal of measures which may prevent any future war. In my study, I want to focus on authors who have claimed that the main causes of war are economic. ${ }^{1}$ The identified economic causes of war have subsequently been followed by changes in economic theory.

I mostly agree with those authors who have emphasized economic factors as a cause of war. On the other hand, I have to refute their approach to the study of the issue in a question which leads to different results in its analyses and, most importantly, to different solutions to the causes of war. In the first part of my essay, I intend to point out the essential elements of the "classical" interpretation of the economic causes of war which are subjected to the persistent influence of Marxism. The second part contains a critique of these economic interpretations. Lastly, I will use the example of John Maynard Keynes and Edvard Beneš to show the consequences of the misapprehension of the causes of war and the subsequent shifts in economic-political thought. The line between Keynes and Beneš can also be perceived as the line between the First World War and the Second World War.

\section{Economic causes of war}

As Lionel Robbins pointed out, the idea of economic causes of war is not a modern one, despite some claims that ancient thinkers and historians only focused on religion, love or power. He also tried to show, for example, that Plato had found causes of war based on economic motives in his Republic. ${ }^{2}$ Of course, the explanation has changed over time in association with changes in the economic and political system. I do not intend to claim that the interpretation of the ancient thinkers has lost its validity, but merely that it would be

1 This does not mean that they have refused any other possible causes, especially political or religious ones. These authors have merely stressed economic factors and motives.

2 Lionel ROBBINS, The Economic Causes of War, New York 1968, 19. 
better to focus only on modern interpretations with regard to this topic.

The Marxist theory of imperialism, class war and exploitation is the necessary starting point. Of course, Karl Marx and his followers did not consider this theory to be universally valid, but only applicable in the capitalist era which inevitably precedes socialism. In other words, for a Marxist socialist „... history becomes a chain of class struggles, until finally, in the modern proletariat there appears a class which can free itself from class rule only by abolishing all class conflicts and all exploitation generally." ${ }^{3}$ However, as I will show later, the original Marxist ideas did not disappear with the fall of his economic system. ${ }^{4}$ Other roots of the economic origins of war and imperialism can be found in the works of Thomas Malthus or Jean Charles de Sismondi. ${ }^{5}$ Briefly summarized, the main idea was the following: due to the low wages for the working class, the workers have too little money to spend. This underconsumption leads to a struggle for foreign markets which can culminate in war - all of this is supported by capitalist institutions and private property. You may say that this idea is very simple, but it is also surprisingly powerful. Probably the best explanation of this economic imperialism comes from the book „Imperialism" by John Atkinson Hobson. "We must have markets for our growing manufactures, we must have new outlets for the investment of our surplus capital and for the energies of the adventurous surplus of our population: such expansion is a necessity of life to a nation with our great and growing powers of production..." is how Hobson described capitalist-imperialist interests and argumentation. ${ }^{6} \mathrm{He}$ then continued by saying that this need of foreign markets leads to the adoption of imperialism as a country's economic policy. As a typical example, Hobson cited the government of President Roosevelt and the exploitation of public resources by big capitalists such as Rockefeller and Morgan. He also explained why imperialist expansion into foreign markets is necessary. In the best Marxist tradition, Hobson wrote that: "The rich will never be so ingenious as to spend enough to prevent over-production. " ${ }^{17}$ In other words, the roots of imperialism lie in the capitalist organization of production and the distribution of wealth. It is now not hard to guess (at) Hobson's solution to the negative effects of imperialism. "Trade Unionism and Socialism are thus the natural enemies of Imperialism, for they take away from the "imperialist" classes the surplus incomes which form the economic stimulus of Imperialism," claimed Hobson. ${ }^{8}$ Hobson was praised for his work by Vladimir Ilyich Lenin in his famous pamphlet „Imperialism: The Highest Stage of Capitalism". 9 For Lenin, there

3 Ludwig von MISES, Socialism: An Economic and Sociological Analysis, Indianapolis 1981, 307. It has to be pointed out that this idea of the inevitable phases of social development is not a Marxist invention. Engels appreciated, for example, the contribution of George Wilhelm Friedrich Hegel or the utopian socialist Charles Fourier. Refer to Friedrich ENGELS, Anti-Dühring, Praha 1949, 221; Friedrich August von HAYEK, Counter-Revolution of Science: Studies on the Abuse of Reason, London 1964, 189-206.

4 By a fall, I mean that the core of the Marxist system was built upon an incorrect theory of value. For example, the surplus value theory, exploitation or the business cycle theory became irrelevant after the marginal revolution. Refer, for example, to Paul SWEEZY (ed.), Karl Marx and the close of his system by Eugen von Böhm-Bawerk \& Böhm-Bawerk's criticism of Marx by Rudolf Hilferding, New York 1949, 3-118.

5 Refer to Vladimír Iljič LENIN, K charakteristice ekonomického romantismu, Praha 1950; ROBBINS, $1968,24$.

6 John Atkinson HOBSON, Imperialism: a Study, New York 1902, 76.

7 Ibidem, 89.

8 lbidem, 96.

9 Refer to Vladimir Ilyich LENIN, Imperialism: The Highest Stage of Capitalism, Chippendale 2008, $25,33$. 
could be no doubt about the statement that the war of 1914-1918 was an imperialist war, an annexationist, predatory war of plunder. Actually, Lenin celebrated this war. For him and his comrades, the First World War was proof that capitalism in its highest stage (i.e. imperialism) is the forerunner to its definite conclusion. In his words: „Imperialism is the eve of the social revolution of the proletariat. "10 The road from capitalism to imperialism is similar in Lenin's work to that in Hobson's. In short, Lenin claimed that free competition under capitalism has led to a monopoly structure in the economy. After the crisis of 1873, the monopolies transformed into cartels. This transformation era lasted until the next capitalist crisis of 1900-1903 when the cartels became the basic structure of the economy. What are the consequences of this development? As Lenin summarized: „The epoch of the latest stage of capitalism shows us that certain relations between capitalist associations grow up, based on the economic division of the world, while parallel to and in connection with it, certain relations grow up between political alliances, between states, on the basis of the territorial division of the world, of the struggle for colonies, of the "struggle for spheres of influence." ${ }^{11}$ There also exists a slightly different point of view to the authors of Marxist-Leninist tradition. The starting point is still the same; the capitalist economy produces excess capital. On the other hand, it does not lead directly to imperialism and international war, because this excess capital is absorbed by the military spending of capitalist countries instead of the struggle for foreign markets. As such, war has to prevent the deterioration of their position. ${ }^{12}$

Now you may say, that I am using only extreme examples of leftist thought, but as I have already mentioned, this approach to the economic origins of war was very powerful. For example, US President Woodrow Wilson said: „Why, my fellow-citizens, is there any man here, or any woman - let me say, is there any child here, who does not know that the seed of war in the modern world is industrial and commercial rivalry? ... This war, in its inception, was a commercial and industrial war. It was not a political war."13 Of course, there is no doubt that Wilson was close to the left, but there is no reason to mark him as a Marxist or a Leninist. Erik von Kuehnelt-Leddihn noted, for example, that Wilson can be called a leftist because of his foreign policy, ${ }^{14}$ but in my opinion this is also possible because of his progressivism and the New Freedom program. ${ }^{15}$ "No one now advocates the old lais-

10 Ibidem, 31, 124-136. Refer also to Philip WARNER, První světová válka, Ostrava 1997, 295.

11 LENIN, 2008, 81. Read about the Marxist theory of colonialism in Karel MARX, Kapitál I, Praha 1953, 805-814.

12 Refer to Jack LEVY, Domestic Politics and War, in: The Journal of Interdisciplinary History, 18, 1988, 4, 653-673. Online: http://www.jstor.org/stable/204819 (Visited: April 2014).

13 This quotation is from a speech which took place in St. Louis, Missouri on 5 September 1919. Refer to John V. DENSON (ed.), The Cost of War: America's Pyrrhic Victories, New Brunswick and London 1999, 503.

14 Refer to Erik von KUEHNELT-LEDDIHN, Leftism: From de Sade and Marx to Hitler and Marcuse, New York 1974, 227-247; Ralph RAICO, World War I: The Turning Point, in: DENSON (ed.), 1999, 209-258.

15 I will explain the definition of socialism later. Read more about Wilson's economic policy in: Arthur LINK, Woodrow Wilson and the Progressive Era 1910-1917, New York 1954, 25-80, 223-251; Alan SELTZER, Woodrow Wilson as a "Corporate-Liberal": Toward a Reconsideration of Left Revisionist Historiography, in: The Western Political Quarterly, 30, 1977, 2, 183-212. Online: http://www.jstor.org/stable/447405 (Visited: April 2014). It is also very important to mention that the Federal Reserve System, the central banking system, was founded during Wilson's presidency. Its consequences have been enormous. Refer to Murray ROTHBARD, A History of Money and Banking in the United States: The Colonial Era to World War II, Auburn 2005, 183-258; Milton FRIEDMAN, Kapitalismus a svoboda, Praha 1993, 44-57. 
sez-faire..." stated Wilson. ${ }^{16}$ The "foreign policy leftism" is therefore especially associated with the person of George Davis Herron. His statement on capitalism and industry was more radical than Wilson's. "Capitalism is but the survival of the animal; the survival of the predatory world of the jungle. Our present industrial world is due to the fact that we have not yet become human; that we are still beasts of prey, fighting with each other for our bread."17

Philip Warner, a military historian, also found the causes of war in the commercial and industrial sphere. In his interpretation, war was inevitable, because of the German will to become the world's industrial power. He also highlighted the investments in heavy industry, military spending and the struggle for foreign colonies. On the other hand, the declining powers also endeavored to preserve their status as world powers. For Warner, people are also naturally aggressive and greedy. ${ }^{18}$ The economist Joseph Russell Smith had a very similar opinion of the origins of war. He stressed three main causes. Firstly, Smith mentioned property as the source of the desire for land, colonies and markets. Then, he turned his attention to preferment - the love of dominion and power. He saw a marked group consciousness which leads to the desire for particularism as the third and last cause of war. Smith, like Wilson, saw the solution in the League of Nations which was supposed to control and protect foreign investments instead of single nations. ${ }^{19}$

A slightly different point of view can be found in the work of John Bakeless. Firstly, he noted that the rise of industrialism had led to a struggle for markets and raw materials. On the other hand, he also appreciated the internationalism of industrialism. Industrialism also had the power to prevent wars due to its interest in preserving the security of its international investments. Unfortunately, Bakeless summarized that „...the economic causes are working a good deal faster towards war than peace." 20 The causes of the First World War can therefore be classified as Anglo-German trade rivalry, Franco-German trade rivalry, the Drang nach Osten and Austrian and Italian economic ambitions. ${ }^{21}$ Bakeless also realized that war is not without costs. Someone has to pay for the soldiers, their weapons and food. The same applies to Richard Hamilton and Holger Herwig. They were stressing technological and economic advance which caused a military revolution. In other words: "A nation's military capacity, at all times, is limited by its economic strength, by its ability to pay." Then, the economic growth itself can be blamed for causing the war. As they concluded: „Ma-

16 Quoted in Martin J. SKLAR, Woodrow Wilson and the Political Economy of Modern United States Liberalism in: A New History of Leviathan: Essays on the Rise of the American Corporate State, Ronald RADOSH - Murray ROTHBARD (ed.), New York 1972, 20.

17 George David HERRON, The Day of Judgment, Chicago 1904, 29.

18 WARNER, 1997, 9-10, 294-298. The role of natural instincts has also been stressed for example in the famous Advocate of Peace journal. „It is true...that there are primordial instincts still alive in the breasts of men...there are fears... The instinct to fight grows out of the instincts of fear. These ancient instincts are the real cause of war." See: Some Causes of War, in: The Advocate of Peace, 77, 1915, 10, 234-235. Online: http://www.jstor.org/stable/20667336 (Visited: April 2014).

19 Joseph Russell SMITH, Economic Internationalism and Peace, 1919, in: The Advocate of Peace, 81, 1919, 8, 246-247. Online: http://www.jstor.org/stable/20668341 (Visited: April 2014).

20 John BAKELESS, The Economic Causes of Modern Wars - A Study of the Period: 1878-1918, New York 1921, vii-viii, 177-195.

21 lbidem, 143. 
chine manufacture had a considerable impact, increasing national wealth and making new weapons possible." 22 Sidney Bradshaw Fay also pointed out the role of population growth. Economic growth allowed a great increase of population which also led to a struggle for new colonies. ${ }^{23}$ After this brief summary of the economic causes of war, now I wish to point out the biggest failures of these interpretations and their most problematic points.

\section{The economic causes of war: A critique}

Firstly, it has to be said that there is no link between capitalism and imperialism. Levy also pointed out that, if one were to accept this link, there would be no evidence of a link between imperialism and war. ${ }^{24}$ Robbins came to the same conclusion in his comprehensive empirical research. In his words, "There is no convincing evidence that it was the struggles of finance capital or the machinations... which were responsible for the outbreak of the Great War." ${ }^{25}$ Where did this theory of capitalist imperialism originate? In my opinion, the roots of this theory lie in a misunderstanding of free market competition and an ideological interpretation of capitalism.

Firstly, competition is equal to the struggle for life and death for many authors. They also often use military terms or expressions with negative connotations to describe an economy based on private property, competition and individual liability. At this point, I want to recall, for example, Wilson's "left hand" Herron and his description of industrial capitalism. For him, capitalism was the "predatory world of the jungle" and people were still beasts fighting each other for food. But as Mises explained „....there exists a fundamental difference between catallactic competition and combat. Competitors aim at excellence and preeminence in accomplishments within a system of mutual cooperation." 26 Then he also described the importance of competition. "The function of competition is to assign to every member of a social system that position in which he can best serve the whole society and all its members. It is a method of selecting the most able man of each performance." 27 In other words, competition is a tool for social coordination in a world of scarcity. Competition and its legal framework are not an invention of capitalists to protect their selfish interests. ${ }^{28}$ Markets and competition are, of course, the products of human action, but they are not created by a few individuals. They are created by a long evolutionary process of

22 Richard HAMILTON - Holger HERWIG, World Wars: Definitions and Causes in: The Origins of World War I, Richard HAMILTON - Holger HERWIG (ed.), Cambridge 2003, 6. Refer also to BAKELESS, 1921, 177.

23 Sidney Bradshaw FAY, The Origins of the World War - Before Sarajevo: Underlying Causes of the War, New York 1930, 44-45.

24 Refer to LEVY, 1988, 663.

25 ROBBINS, 1968, 57.

26 Ludwig von MISES, Human Action: A Treatise on Economics, Auburn 1998, 117.

27 Ibidem, 117.

28 The market process and law creation have been superbly described by Bruno Leoni. As he pointed out, „„... there is more than an analogy between the market economy and a judiciary or lawyers' law, just as there is much more than an analogy between a planned economy and legislation." Refer to Bruno LEONI, Freedom and the Law, Los Angeles 1972, 22. 
social coordination. ${ }^{29}$ Using economic argumentation, the final reply to Herron can be that „... [The market economy] is the strategy, as it were, by the application of which man has triumphantly progressed from savagery to civilization. "30

I have also mentioned the argument that private property is the source of the desire for land, colonies and markets. Its role in the process of social coordination is equally important. Any reflections on private property should first start with its origin. One of the basic qualities of the real world is scarcity; scarcity of material resources. As such, there are two possible problems to be solved. First, how to improve the economic conditions of people and to reach prosperity despite the lack of resources. Secondly, how to prevent conflict for these resources in society. "Law\&Economics" gives us an answer. The origin of the economy based on private property is not the invention of "evil capitalists" protecting their selfish interests, but „...human economy and property have a joint economic origin since both have, as the ultimate reason for their existence, the fact that goods exist whose available quantities are smaller than the requirements of men. Property, therefore, like human economy, is not an arbitrary invention but rather the only practically possible solution of the problem that is in the nature of things, imposed upon us by the disparity between requirements for, and available quantities of, all economic goods." 31 Richard Pipes also summarized this in his historical research by stating that property is not an institution given by law or legislation, but a natural institution common for all societies. ${ }^{32}$ This so-called natural institution does not mean an institution given by God or anything metaphysical. Natural is used in the sense of spontaneous adaptation to the conditions of the real world. That means scarcity. ${ }^{33}$ This has been excellently explained by Jean-Baptiste Say: "If the state of nature is for man the one in which he obtains his greatest development, if he attains this development only in the state of society, and if the state of society can survive only with property, then the right of property is therefore a natural one: it derives therefore from the very nature of man..." 34 Property therefore gives us clear borders for individuals' actions and prevents conflict. For example, Ludwig von Mises or Friedrich August von Hayek has also explained that property is crucial for the economic calculation in the socialist calcula-

29 Friedrich August von Hayek made a great contribution to the evolutionary social processes. Refer to Friedrich August von HAYEK, Law, Legislation and Liberty, London 1982, 8-180; Robert SUGDEN, Spontaneous Order, in: The Journal of Economic Perspectives, 3, 1989, 4, 85-97. Online: http://www.jstor.org/stable/1942911 (Visited: May 2014). See also Murray ROTHBARD, Man, Economy and the State with Power and Market, Auburn 2009, 629-754.

30 MISES, 1998, 266.

31 Carl MENGER, Principles of Economics, Auburn 2011, 97.

32 Richard PIPES, Property and Freedom, New York 1999, 116. Read more about the origin of property in MISES, 1981, 27-44; DEMSETZ, Harold: Toward a Theory of Property Rights, in: The American Economic Review, 57, 1967, 2, 347-359. Online: http://www.jstor.org/stable/1821637 (Visited: May 2014).

33 There are few socialist authors who have rejected the existence of a scarcity of material resources and have claimed that the scarcity is caused by the social order and the unfair redistribution of wealth. Refer for example to MORELLY, Zákoník prírody, Praha 1958, 36; Robert OWEN, Vybrané spisy, Praha 1960, 81. Actually, these visions are only fallacies of utopian socialists and the non-existence of scarcity has never been proven. Refer to Frank van DUN, Concepts of Order, in: Hardy BOUILLON - Hartmut KLIEMT, Ordered Anarchy: Jasay and his Surroundings, Padstow 2007, 59-92; Tomáš NIKODYM, Z knihovničky utopického socialismu, Praha 2014.

34 Quoted in Heath PEARSON, Origins of Law and Economics: The Economists' New Science of Law 1830-1930, New York 1997, 8. 
tion debate. ${ }^{35}$

The claim that a free market economy leads to the monopolization and cartelization of the capitalist economy is also misleading. Once again, this incorrect claim is based on a lack of knowledge of economics. Actually, not even history confirms this statement. The fallacy of the aforementioned approach lies in the fact that these authors have only focused on the results and the final structure of the economy and not on the processes leading to these results. Ignoring the processes leads to the misunderstanding of free markets and capitalism itself. As Pascal Salin explained, „The number of firms in a specific market at one given time is the provisional outcome of a specific process and it has no meaning by itself. On the contrary, the fact that the process is based on the use of public constraint or is purely spontaneous makes the difference. "36 Economic theory shows us that the existence of a monopoly is not a result of the market process. There is still competition in the market, and the only firm in the market can still be competitive and the most effective result of the market process. In other words, competition does not depend on the number of producers in the chosen market, but on the freedom of entry into the industry. ${ }^{37}$ The same applies to cartels. „...there is no such thing as monopoly of power, as far as the process of monopolization by cartels is spontaneous," wrote Salin. ${ }^{38}$ Historical study also supports the theoretical conclusions. Actually, Lenin was right when he claimed that the monopolies transformed into cartels after the crisis of 1873, but he missed one important point; it was not spontaneous cartelization. „The period after 1873 was...sometimes known as the ,modern cartel era', was more a period of government created cartels than spontaneously created ones," explained Lukáš Nikodym in his study. ${ }^{39}$ In other words, Lenin and other authors underestimated the crucial role of the government in the economy. The following results of their analysis suffer from the same mistakes. At this point, it is very important to realize that the "capitalists" themselves have no legal or military power to annex, plunder and fight. Blaming capitalism or the free market for imperialism and war is a hasty and ideological explanation. Of course, there is no doubt that efforts by various interest groups or entrepreneurs to use governmental regulation in their favor may arise, but these bene-

35 MISES, 1981, 95-194; Ludwig von MISES, Economic Calculation in the Socialist Commonwealth, 1990. Online: http://mises.org/pdf/econcalc.pdf (Visited: May 2014). After Mises, Friedrich August von Hayek continued the debate on economic calculation. Refer to Friedrich August von HAYEK, The Use of Knowledge in Society, in: American Economic review, 35, 1945, 4, 519-530. Online: http://www.jstor.org/ stable/1809376 (Visited: May 2014); Friedrich August von HAYEK, Individualism and Economic Order, Chicago 1958, 119-208. See also Murray ROTHBARD, The End of Socialism and the Calculation Debate Revisited, in: The Review of Austrian Economics, 5, 1991, 2, 51-76. Online: https://mises.org/journals/rae/pdf/rae5_2_3.pdf (Visited: June 2014).

36 Pascal SALIN, Cartels as Efficient Productive Structures, in: The Review of Austrian Economics 9, $1996,2,30$. Online: http://mises.org/journals/rae/pdf/rae9_2_2.pdf (Visited: May 2014).

37 Refer to ROTHBARD, 2009, 629-754; Israel KIRZNER, How Markets Work: Disequilibrium, Entrepreneurship and Discovery, London 1997, 58-63; Dominick ARMENTANO, Antitrust: The Case for Repeal, Auburn 2007.

38 SALIN, 1996, 32.

39 Lukáš NIKODYM, Theoretical Aspects of Cartelization in Central Europe, in: Central European Papers, 2, 2014, 1. This statement is also supported by the old study of Austro-Hungarian business legislation. František Čuhel and Rudolf Hotowetz pointed out that despite some liberal measures ("liberal" is used in the European sense, not from the American point of view where "liberal" means socialist), the industrialists and the entrepreneurs were forced to create business associations and cartels. Refer to František ČUHEL - Rudolf HOTOWETZ - Josef GRUBER, Obchodní sborník: Obchodní a živnostenské korporace, svépomocná sdružení a obchodní ústavy vzdělávací, Praha 1899, 1. 
fits are fully dependent on political decision-making and there is an insuperable difference between „pure competition" and the competition within a regulated economy.

As Franz Oppenheimer explained, there are two ways of reaching individual goals. First, there are economic means and secondly there are political means. „There are two fundamentally opposed means whereby man, requiring sustenance, is impelled to obtain the necessary means for satisfying his desires" wrote Oppenheimer. "These are work and robbery, one's own labor and the forcible appropriation of the labor of others... propose... to call one's own labor and the equivalent exchange of one's own labor for the labor of others the ,economic means'... while the unrequited appropriation of the labor of others will be called the ,political means'..." As such, it is easy to summarize that "The state is an organization of political means." ${ }^{40}$ The same approach has to be applied to the difference between the free market and a regulated economy. Then we are able to compare voluntary exchanges in markets and governmental interventionism. With regard to voluntary exchanges, we know that both parties to the exchange are better off. Voluntary exchanges improve the conditions of both parties; this means that no one is hurt by the exchange and no one gains any benefits to the detriment of the second party in the exchange. No one accepts an exchange without benefits. ${ }^{41}$ If someone tries to violate a voluntary exchange and force the second party to buy/do something against his/her will, the contract is not valid. That means that not even "evil capitalists" have any legal power to enforce an involuntary exchange. On the other hand, the conditions will change with governmental intervention, legislation and its coercive apparatus. ${ }^{42}$ As Rothbard explained, "In the market, therefore, there can be no such thing as exploitation...But as soon as intervention appears on the scene, conflict is created, for each person or group may participate in a scramble to be a net gainer rather than a net loser - to be part of the intervening team, as it were, rather than one of the victims." 43 In other words, if there is a chance for some individuals or groups to live at the expense of others, this chance will be seized. Defeating other competitors is much easier through the political process than through innovations and consumer service; i.e. the market process. As such, so-called economic policy can be used against domestic and foreign inhabitants or entrepreneurs. Actually, there is no difference between these two policies. For example, a "typical domestic" policy such as consumer protection is a kind of protectionism against foreign goods. Regulations such as quality standards or compulsory instructions in a native language can be used instead of "visible" protections like duties or import quotas. The only goal of consumer protection is to exclude foreign goods from the domestic market. It is not the free market or capitalism which leads to a sense of injustice and tussles to acquire foreign markets; rather it is the economic policy adopted by the government. Of course, all kinds of governmental protections and intervention may

40 Franz OPPENHEIMER, The State, New York 1914, 24-27.

41 It has to be emphasized that we cannot measure the benefits in money or in any other way. The benefits are only the subjective feeling of individuals voluntarily accepting the exchange.

42 For example Rothbard distinguished between 3 kinds of governmental intervention - autistic, binary and triangular intervention. Refer to ROTHBARD, 2009, 875-1295. On the other hand, Mises identified only two kinds of most common intervention: interference by restriction and interference by price control. Refer to Ludwig von MISES, Omnipotent Government: The Rise of the Total State and Total War, Indianapolis 2011, 71.

43 ROTHBARD, 2009, 881. 
lead to war. "If goods don't cross borders, armies will"44 In my opinion, the causes of war should not be sought in domestic of foreign policy, but in the existence of any policy. From this point of view, socialism has to be designated as a primary cause of war. All of the interpretations of the origins of war which I have mentioned above failed to understand what capitalism is and what it is not. Of course, there is no doubt that capitalism is an economic system based on private property, but no advocate of capitalism supports protectionism, active monetary policy (which is actually also a very powerful protectionist tool), bank bailouts etc. Actually, all of these types of regulation can be called socialist. As Hans-Herman Hoppe explained, „....socialism...must be conceptualized as institutionalized interference in or aggression against private property and private property claims." 45 On the other hand, capitalism has to be seen as a system based on private property and voluntary contractual exchanges. Governmental intervention and regulations do not fit into this framework. The same applies to the dynamic definition of socialism by Jesús Huerta de Soto. He extended Hoppe's definition to include Israel Kirzner's entrepreneurial discovery. Huerta de Soto realized that the results of governmental interventionism are almost identical to socialism, because interventionism also disrupts social coordination. Then „„...socialism is all systematic and institutionalized aggression that restricts the free performance of entrepreneurship in a determined social area and that is carried out by a controlling organism which is in charge of the tasks of social co-ordination necessary in said area." 46 This point made by Huerta de Soto leads me to an another difference between voluntary cooperation and institutionalized aggression (interventionism, socialism). Voluntary cooperation excludes any institutionalized aggression. I do not wish to claim that people will be as peaceful as angels in a system based on private property and voluntary cooperation, but, if a contractual exchange is violated, there is always an institution standing above the individuals and protecting human lives and private property. In other words, any aggression will be punished and the aggressor can never profit by violating these rights. ${ }^{47}$ This does not apply to government intervention. Unfortunately it also does not apply to the state in international relations. So, while aggression at an individual level is always very expensive, because the aggressor has to recompense the victim's losses plus all the expenses incurred as a result of the aggression, the situation is different at an international level. There is no institution standing above states or groupings of states. In this case, aggression (called war at an international level) is less expensive than aggression at an individual level. Not only does the government cover the costs of war with taxes or inflation, but it also does not recompense the victims' losses and expenses after a victorious war. It is inconceivable that, for example, Hitler's Germany would have paid compensation to all the victims of war, if the Nazis had been victorious. In short, it is not capitalism (as a system based on private property and voluntary contractual exchange), but interventionism (socialism, institutionalized

44 This quotation is often attributed to Frédéric Bastiat but it has never been proved that he said it.

45 Hans-Herman HOPPE, A Theory of Socialism and Capitalism, Auburn 2010, 10.

46 Jesús HUERTA DE SOTO, Entrepreneurship and the Economic Analysis of Socialism, in: New Perspectives on Austrian Economics, Gerrit MEIJER (ed.), London 1995, 240.

47 There are many works describing voluntary societies and their legal systems. Refer, for example, to Morris TANNEHILL - Linda TANNEHILL, The Market for Liberty, Auburn 2007; Edward STRINGHAM (ed.), Anarchy and the Law: Political Economy of Choice, Oakland 2009; Murray ROTHBARD, Ethics of Liberty, New York 1998. 
aggression) which leads to the adoption of conquering policies and imperialism. Firstly, interventionist domestic or foreign policies lead to a struggle between interest groups for the use of the "political means" mentioned by Oppenheimer or they lead to retaliatory action taken by other governments. Secondly, it has been shown that barriers preventing aggression often do not exist at an international level, as they exist at an individual level. Thirdly, it is much cheaper to adopt imperialism as governmental policy and to wage war for an interventionist (socialist) government.

\section{From Keynes to Beneš: Economic theory between wars}

Misunderstanding the causes of war is not without its consequences. As I have stated above, the identified economic causes of war have been followed by changes in economic theory and, of course, economic policy. Now, I want to show these consequences using the example of John Maynard Keynes and Edvard Beneš. Both of them came up with proposals for government actions which would prevent future wars and preserve "western society." Unfortunately, their analyses of the causes of war suffered from the same mistakes as those which I have explained in the previous part of the essay.

After World War One, Keynes realized that there was not only one cause of war. On the other hand, he stressed the role of economic motives as the easiest way of igniting the flames of passion and hate. In the best Malthusian tradition, Keynes claimed that the main economic cause of war was population growth which leads to unemployment, which is a typical feature of individualist capitalism. The government then has to fight for foreign markets to solve its internal economic problem of unemployment. „....under the system of...'laissez-faire' and an international gold standard such as was orthodox in the latter half of the nineteenth century, there was no means open to a government whereby to mitigate economic distress at home except through the competitive struggle for markets," stated Keynes. ${ }^{48}$ The struggle for markets leads to a clash of nations and eventually it leads to war. His goal was therefore to find a solution to unemployment using the tools of domestic policy without foreign expansion and the methods of authoritative regimes. In his words, „... it may be possible by a right analysis of the problem to cure the disease whilst preserving efficiency and freedom." 49 Later, Keynes' approach was distorted by his followers and the liberty of the individual completely disappeared. For example, Joan Robinson wrote that "Hitler found a cure against unemployment before Keynes was finished explaining it." ${ }^{50}$ Actually, despite Keynes' claims about individual liberty, his proposals for governmental intervention were very similar to the "German type of socialism." At this point, I do not

48 John Maynard KEYNES, The General Theory of Employment, Interest and Money, London 1936, 382.

49 Ibidem, 381.

50 Quoted in Llewellyn ROCKWELL, Hitler's Economic, URL: http://mises.org/library/hitlers-economics (Visited: July 2014). The same applies to John Kenneth Galbraith. He claimed that Hitler „....was the true protagonist of Keynesian ideas." (Refer to Bruce BARTLETT, Keynesian Policy and Development Economics, in Dissent on Keynes: A Critical Appraisal of Keynesian Economics, Mark SKOUSEN (ed.), New York 1992, 115). 
want to undertake an extensive analysis of Keynesian economics, ${ }^{51}$ but to show that the basic principles of his economic policy could not fulfill the promised results due to a misunderstanding of the economic causes of war. What was Keynes” "miraculous cure" for the preservation of western society?

For Keynes, it was impossible to reach full employment without government intervention. "I conclude that the duty of ordering the current volume of investment cannot safely be left in private hands, " claimed Keynes. ${ }^{52}$ As such, the proposed solution was based on the wide socialization of private investments and the regulation of the propensity to consume. On the other hand, Keynes still insisted that after socialization and regulation „...there will... remain a wide field for the exercise of private initiative and responsibility." 53 Actually, the socialization of investments is an unprecedented offence against private property which has been shown to be the basis of individual liberty and initiative. Unfortunately, Keynes never fully understood the role of private property in the economy. Right after the war, he wrote that „...the sharp distinction...between the property and rights of a state and the property and rights of its nationals is an artificial one, which is being rapidly put out of date by many other influences than the peace treaty, and is inappropriate to modern socialistic conceptions between the state and its citizens." ${ }^{54}$ The problem is that private initiative, which Keynes wanted to preserve, is fully dependent on the form of ownership. Only if there is private property are men able to set their own goals and enjoy the fruits of their initiative and voluntary cooperation. In other words, Keynes did not introduce a "new system" which combines individualism with government intervention, but only another form of socialism. As Hazlitt explained, "Investment is a key decision in the operation of any economic system. And government investment is a form of socialism. Only confusion of thought, or deliberate duplicity, would deny this. For socialism, as any dictionary would tell the Keynesians, means the ownership and control of the means of production by government. Under the system proposed by Keynes, the government would control all investment in the means of production and would own the part it had itself directly invested. It is at best mere muddle headedness, therefore, to present the Keynesian nostrums

51 Actually, it has already been made. A great critique was made, for example, by Henry Hazlitt or Friedrich August von Hayek. Refer to Henry HAZLITT, The Failure of the "New Economics": An Analysis of the Keynesian Fallacies, Toronto - New York - London 1959; Friedrich August von HAYEK, A Tiger by the Tail: The Keynesian legacy of inflation, London 1978; Bruce CALDWELL (ed.), The Collected Works of F. A. Hayek: Contra Keynes and Cambridge - Essays, Correspondence, Chicago 1995; David SANZ BAS, Hayek's Critique on The General Theory: A New View of the Debate Between Hayek and Keynes, in: The Quarterly Journal of Austrian Economics, 14, 2011, 3, 288-310. URL: https://mises.org/journals/qjae/pdf/qjae14_3_2.pdf (Visited: June 2014); Hunter LEWIS, Where Keynes went wrong: and why world governments keep creating inflation, bubbles, and busts, Mount Jackson 2009.

52 KEYNES, 1936, 320.

53 Ibidem, 380.

54 John Maynard KEYNES, The Economic Consequences of the Peace, New York 1920, 71-72. The same approach also applies to other Keynesians like Robinson, Samuelson or Solow. For example, Samuelson claimed that institutions (i.e. also the institution of property) do not belong to the sphere of interest of economics. Robinson was more radical and she completely rejected property. She wrote that private property is useless. Solow made a similar point when he stated that private property has to prove its meaning. Refer to Josef ŠímA, Ekonomie a právo, Praha 2004, 16. 
as a free enterprise or ,individualistic' alternative to socialism. "55 The consequences of socialism have been explained in the previous section of this paper. It is also important to mention Keynes' return to mercantilism. He claimed that the advantages of international trade and labor division had been overstressed. On the other hand, Keynes praised mercantilists for their "realism" which was supposedly better than the "confused thinking" of the laissez-faire advocates. In his opinion, laissez-faire policy could not avoid war. Keynes' other inspiration came from Silvio Gesell. Gesell introduced the non-Marxist theory of a just social order. Part of this theory also involved a new monetary policy based on abolishing the gold standard. ${ }^{56} \mathrm{His}$ work, like that of Keynes, was a reaction to laissez-faire policies and Marxism. Their goal was to propose a "third" system combining the advantages of both systems. ${ }^{57}$ Unfortunately, there is no third way. Keynes's interventionism has consequences for social coordination similar to socialism and we know from the previous section of this paper that socialism has no means for rational economic calculation. As Mises pointed out, "The choice for mankind is not between two economic systems. It is between capitalism and chaos." 58 To put it briefly, Keynesian attempts to combine interventionism with individual freedom were futile from the outset. Finally, Keynes himself was aware of the fact that economic policies based on his theories were more compatible with a totalitarian state than with a free society based on private property and individual incentives. In the foreword to the German edition of his General Theory Keynes wrote that, "The theory of output as a whole, which is what the following book purports to provide, is much more easily adapted to the conditions of a totalitarian state, than is the theory of the production and distribution of a given output produced under conditions of free competition and a large measure of laissez-faire." 59

After the fail of interventionism during the 1920s and 1930s, another war broke out. Unfortunately, even after World War Two, the interpretation of the causes of war did not change. Actually, it even got worse because interventionism became a standard economic policy. Then the shift in economic theory was more radical than after World War One. A great example was provided by Edvard Beneš, the president of Czechoslovakia.

Beneš, like Keynes after the First World War, saw the causes of war as lying in the inefficiency of "bourgeois liberal democracy" to solve the economic and social problems of society. He stated that even social legislation and reformism in progressive countries had not resolved the main social problems such as unemployment. Beneš then concluded that the economic system of bourgeois democracy required radical reorganization. On the other hand, the political errors of these democracies did not require any significant changes. ${ }^{60}$ "It is necessary to implement extensive collectivist and socialization measures,"

\footnotetext{
55 HAZLITT, 1959, 388.
}

56 As also Keynes pointed out in 1924, "In truth, the gold standard is already a barbarous relic." Quoted in Michael BORDO - Anna SCHWARTZ, A Retrospective on the Classical Gold Standard 1821-1931, Chicago $1984,79$.

57 KEYNES, 1936, 353-358, 379-380. Refer also to Murray ROTHBARD, Keynes, the Man, in: Dissent on Keynes: A Critical Appraisal of Keynesian Economics, Mark SKOUSEN (ed.), New York 1992, 186-187.

58 MISES, 2011, 65.

59 BARTLETT, 115.

60 Refer to Edvard BENEŠ, Demokracie dnes a zítra, Praha 1946, 244-245. 
wrote Beneš. ${ }^{61}$ His vision of a "new order" was the combination of western democracy in the political sphere of society and the Soviet planned economy in the social and economic spheres. Beneš believed that individual liberty is based on the political system and that the economy can be fully controlled by a democratically elected government without any loss of freedom. Unfortunately, the consequences of this approach were devastating. As Friedrich August von Hayek explained, the liberty of the individual is indivisible. „The economic freedom which is the prerequisite of any other freedom cannot be the freedom from economic care which the socialists promise us and which can be obtained only by relieving the individual at the same time of the necessity and of the power of choice..." 62 In other words, in a planned economy an individual's entire life is controlled by government authority. Private property and individual incentives are fully subordinated to the government. Put briefly, Beneš introduced just another form of socialism, like Keynes. His misunderstanding of the causes of war followed by the changes in economic policy in Czechoslovakia helped to accelerate the process of the total socialization of the economy, the political dictatorship of communist party and forty years of the fear of war.

\section{Conclusion}

In my paper, I have endeavored to highlight the problematic points in the economic interpretations of the origins of war. It has been shown that the most common interpretations are still influenced by Marxist theories. On this theoretical basis, economists, historians and various intellectuals have designated commerce, private property, economic growth, cartels or capitalism itself as causes of war. Unfortunately, all of these interpretations have underestimated the role of the government in the economy. After the definition of the terms of capitalism and socialism, it has been explained that the presented causes of war with subsequent economic policy measures have been exposed as having a poor theoretical basis. The described economic origins of war are therefore not valid. At the beginning of this paper, I stated that I mostly agree with authors who emphasize economic factors as causes of war. I still do. On the other hand, it is necessary to adopt a different point of view on this issue. Using economic theory, it has been shown that the economic causes of war do not lie in the existence of private property or capitalism. There is no evidence as to the fact that capitalism itself leads to economic imperialism. Actually, the economic causes have been described as a result of governmental intervention and protectionism: in a word, socialism. The same applies to measures which may prevent future wars. It has been shown using the example of John Maynard Keynes and Edvard Beneš that more governmental intervention is not the right way to preserve western society and prevent wars. More and more governmental intervention leads to the rise of State power and the weakening of in-

\section{Ibidem.}

62 Friedrich August von HAYEK, Road to serfdom, New York 2001, 104. Hayek also quoted Hilaire Belloc. "The control of the production of wealth is the control of human life itself," wrote Belloc (lbidem, 91). For example, another Czechoslovak politician - Karel Engliš also realized that there is no individual liberty without an economic one. As he explained during his speech in 1947, "Where economic liberalism is knocked down, the authoritative planning extends to the political sphere... The State which controls the economy wants to control the thoughts of the whole Nation to secure its planned economic system." Refer to Karel ENGLIŠ, Svoboda myšlení a přesvědčení, in: František VENCOVSKY, Karel Engliš, Brno 1993, 125. 
dividual liability and incentives based on private property. It not only leads to the struggle of various interest groups for economic benefits, but it also breaks down the barriers which may prevent conflict at an individual level. At the very end, I have to repeat the statement that the causes of war should not be sought in domestic or foreign policies, but in the existence of any economic policy.

\section{Abstract}

The paper deals with various economic interpretations of World War I which are often followed by changes in economic theory. It is shown, that most prevailing interpretations are still influenced by Karl Marx and his theories. Then, the sequential shift in economic or social policy and thinking is inevitably influenced by Marxism too. Authors writing in this tradition summarized that the capitalism leads to the monopolist structure of the economy and to the imperialism in economic policy. The war is then result of the struggle for foreign markets and resources. Using the economic theory and clarifying basic definition (for example competition, capitalism, socialism) the paper shows that it is not the "invisible hand" of capitalism what is a cause of war, but the "visible hand" of the state.

\section{Keywords}

World War One, capitalism, imperialism, socialism

\section{References}

ARMENTANO, Dominick: Antitrust: The Case for Repeal, Auburn 2007.

BAKELESS, John: The Economic Causes of modern Wars - A Study of the Period 1878-1918, New York 1921.

BENEŠ, Edvard: Demokracie dnes a zítra, Praha 1946.

BORDO, Michael - SCHWARTZ, Anna (eds.): A Retrospective on the Classical Gold Standard, 1821-1931, Chicago 1984.

CADWELL, Bruce (ed.): The Collected Works of F. A. Hayek: Contra Keynes and Cambridge - Essays, Correspondence, Chicago 1995.

ČUHEL, František - HOTOWETZ, Rudolf - GRUBER, Josef: Obchodní sborník: Obchodní a živnostenské korporace, svépomocná sdružení a obchodní ústavy vzdělávací, Praha 1899.

DEMSETZ, Harold: Toward a Theory of Property Rights, in: The American Economic Review, 57, 1967, 2 (Papers and Proceedings of the Seventy-ninth Annual Meeting of the American Economic Association), 347-359.

DENSON, John (ed.): The Cost of War: America's Pyrrhic Victories, New Brunswick and London 1999.

DUN, Frank van: Concepts of Order, in: Ordered Anarchy: Jasay and his Surroundings, BOUILLON, Hardy - KLIEMT, Hartmut (eds.), Padstow 2007, 59-92.

ENGELS, Bedřich: Anti-Dühring: Pana Evžena Dühringa převrat vědy, Praha 1949.

ENGLIŠ, Karel: Svoboda myšlení a přesvědčení, in: VENCOVSKÝ, František: Karel Engliš, Brno 1993, 122-130. 
FAY, Sidney Bradshaw: The Origins of the World War - Before Sarajevo: Underlying Causes of the War, New York 1930.

FRIEDMAN, Milton: Kapitalismus a svoboda, Praha 1993.

HAMILTON, Richard - HERWIG, Holger: World Wars: Definitions and Causes in: The Origins of World War I, HAMILTON, Richard - HERWIG, Holger (ed.), Cambridge 2003, 1-44.

HAYEK, Friedrich August von: A Tiger by the tail: The Keynesian legacy of inflation, London 1978.

HAYEK, Friedrich August von: Counter-Revolution of Science: Studies on the Abuse of Reason, London 1964.

HAYEK, Friedrich August von: Individualism and Economic Order, Chicago 1958.

HAYEK, Friedrich August von: Law, Legislation and Liberty, London 1982.

HAYEK, Friedrich August von: The Road to Serfdom, New York 2001.

HAYEK, Friedrich August von: The Use of Knowledge in Society, in: The American Economic Review, 35, 1945, 4, 519-530.

HAZLITT, Henry: The Failure of the "New Economics": An Analysis of the Keynesian Fallacies, Toronto - New York - London 1959.

HERRON, David George: The Day of Judgment, Chicago 1904.

HOBSON, John Atkinson: Imperialism: a Study, New York 1902.

HOPPE, Hans-Hermann: A Theory of Socialism and Capitalism, Auburn 2010.

HUERTA DE SOTO, Jesús: Entrepreneurship and the Economic Analysis of Socialism, in:

New Perspectives on Austrian Economics, Gerrit MEIJER (ed.), London 1995, 228-252.

KEYNES, John Maynard: The Economic consequences of the Peace, New York 1920.

KEYNES, John Maynard: The General Theory of Employment, Interest and Money, London 1936.

KIRZNER, Israel: How Markets Work: Disequilibrium, Entrepreneurship and Discovery, London 1977.

KUEHNELT-LEDDIHN, Erik von: Leftism: From de Sade and Marx to Hitler and Marcuse, New York 1974.

LENIN, Vladimír ljič: K charakteristice ekonomického romantismu, Praha 1950.

LENIN, Vladimir Iljyich: Imperialism: The Highest Stage of Capitalism, Chippendale 2008.

LEONI, Bruno: Freedom and the Law, Los Angeles 1972.

LEVY, Jack: Domestic Politics and War, in: The Journal of Interdisciplinary History, 18, 1988, 4, 653-673.

LEWIS, Hunter: Where Keynes went wrong: And why world governments keep creating inflation, bubbles, and busts, Mount Jackson 2009.

LINK, Arthur: Woodrow Wilson and the Progressive Era 1910-1917, New York 1954.

MARX, Karel: Kapitál I, Praha 1953.

MENGER, Carl: Principles of Economics, Auburn 2011.

MISES, Ludwig von: Economic Calculation in The Socialist Commonwealth, URL: http://mises.org/pdf/econcalc.pdf.

MISES, Ludwig von: Human Action: A Treatise on Economics, Auburn 1998.

MISES, Ludwig von: Omnipotent Government: The Rise of the Total State and Total War, Indianapolis 2011. 
MISES, Ludwig von: Socialism: An Economic and Sociological Analysis, Indianapolis 1981. MORELLY: Zákoník prírody, Praha 1958.

NIKODYM, Lukáš: Theorethical Aspects of Cartelization in Central Europe, in: Central European Papers, 2, 2014, 1 25-38.

NIKODYM, Tomáš: Z knihovničky utopického socialismu, Praha 2014.

OPPENHEIMER, Franz: The State: Its History and Development Viewed Sociologically, New York, 1914.

OWEN, Robert: Vybrané spisy, Praha 1960.

PEARSON, Heath: Origins of Law and Economics: The Economicsts' New Science of Law 1830-1930, New York 1997.

PIPES, Richard: Property and Freedom, New York 1999.

ROCKWELL, Llewellyn: Hitler's Economics, URL: http://mises.org/library/hitlers-economics. ROBBINS, Lionel: The Economic Causes of War, New York 1968.

ROTHBARD, Murray: A History of Money and Banking in the United States: The Colonial

Era to World War II, Auburn 2005.

ROTHBARD, Murray: Ethics of Liberty, New York 1998.

ROTHBARD, Murray: Man, Economy and the State with Power and Market, Auburn, 2009.

ROTHBARD, Murray: The End of Socialism and the Calculation Debate Revisited, URL: https://mises.org/journals/rae/pdf/rae5_2_3.pdf.

SALIN, Pascal: Cartels as Efficient Productive Structures, in: The Review of Austrian Economics, 9, 1996, 2, 29-42.

SANZ BAS, David: Hayek's Critique of The General Theory: A New View of the Debate between Hayek and Keynes, in: The Quarterly Journal of Austrian Economics, 14, 2001, 3, 288-310.

SELTZER, Alan: Woodrow Wilson as "Corporate-Liberal": Toward a Reconsideration of Left

Revisionist Historiography, in: The Western Political Quarterly, 30, 1977, 2, 183-212.

SKLAR, Martin J.: Woodrow Wilson and the Political Economy of Modern United States Liberalism in: A New History of Leviathan: Essays on the Rise of the American Corporate State, RADOSH, Ronald - ROTHBARD, Murray (ed.), New York 1972, 7-65.

SKOUSEN, Mark (ed.): Dissent on Keynes: A Critical Appraisal of Keynesian Economics, New York 1992.

SMITH, Joseph Russell: Economic Internationalism and Peace, in: The Advocate of Peace, $81,1919,8,246-247$.

Some Causes of War, in: The Advocate of Peace, 77, 1915, 10, 234-235.

STRINGHAM, Edward: Anarchy and the Law: Political Economy of Choice, Oakland, 2009. SUGDEN, Robert: Spontaneous Order, in: The Journal of Economic Perspectives, 3, 1989, 4, 85-97.

SWEEZY, Paul (ed.): Karl Marx and the Close of his System by Eugen von Böhm-Bawerk \& Böhm-Bawerks Criticism of Marx by Rudolf Hilferding, New York, 1949.

ŠímA, Josef: Ekonomie a právo, Praha 2004.

TANNEHILL, Morris - TANNEHILL, Linda: The Market for Liberty, Auburn 2007.

WARNER, Philip: První světová válka, Ostrava 1997. 